Short Communication

\title{
Size Effect on Electrochemical Performance of Sodium Terephthalate as Anode Material for Sodium-Ion Batteries
}

\author{
Yi $\mathrm{Li}^{\dagger}$, Xianfei $\mathrm{Hu}^{\dagger}$, Haoqing Tang ${ }^{*}$ \\ School of Chemical Engineering and Technology, Tianjin University, Tianjin 300350, China \\ ${ }^{\dagger}$ These authors contributed equally \\ *E-mail: liyi-work@qq.com
}

doi: $10.20964 / 2018.07 .81$

Received: 22 March 2018 / Accepted: 17 May 2018 / Published: 5 June 2018

\begin{abstract}
Sodium-ion batteries (SIBs) have been recently regarded as one of the most powerful alternatives for lithium ion batteries. Owing to their multi-electron reaction mechanism and low cost, organic anode materials with suitable redox potential and high specific capacity are gradually applied in SIBs. In this article, sodium terephthalate $\left(\mathrm{Na}_{2} \mathrm{C}_{8} \mathrm{H}_{4} \mathrm{O}_{4}, \mathrm{Na}_{2} \mathrm{TP}\right)$ was synthesized through acid-base neutralization method. Then, $\mathrm{Na}_{2} \mathrm{TP}$ with different sizes was obtained by anti-solvent method and applied as anode material for SIBs. The electrochemical performance of $\mathrm{Na}_{2} \mathrm{TP}$ improves with its size reducing. When the average size of $\mathrm{Na}_{2} \mathrm{TP}$ is $8 \mu \mathrm{m}$, the reversible specific capacity reaches $225 \mathrm{mAh} / \mathrm{g}$ in the first cycle and remains $166.1 \mathrm{mAh} / \mathrm{g}$ after 50 cycles.
\end{abstract}

Keywords: Sodium-ion batteries; sodium terephthalate; anti-solvent; size adjustment

\section{FULL TEXT}

(C) 2018 The Authors. Published by ESG (www.electrochemsci.org). This article is an open access article distributed under the terms and conditions of the Creative Commons Attribution license (http://creativecommons.org/licenses/by/4.0/). 